Journal of

Psychopharmacology

\title{
Alternative splicing on serotonergic system: implications in neuropsychiatric disorders
}

\begin{tabular}{|c|c|}
\hline J ournal: & Journal of Psychopharmacology \\
\hline Manuscript ID & JOP-2018-3657.R2 \\
\hline Manuscript Type: & Review \\
\hline $\begin{array}{l}\text { Date Submitted by the } \\
\text { Author: }\end{array}$ & 15-May-2019 \\
\hline Complete List of Authors: & $\begin{array}{l}\text { Latorre, Eva; University of Exeter Medical School, Molecular Genomics } \\
\text { Mesonero, Jose Emilio; Universidad de Zaragoza, Departamento } \\
\text { Farmacología y Fisiología } \\
\text { Harries, Lorna; University of Exeter Medical School, Molecular Genomics }\end{array}$ \\
\hline $\begin{array}{r}\text { Please list at least } 3 \text { keywords } \\
\text { which relate to your } \\
\text { manuscript: : }\end{array}$ & $\begin{array}{l}\text { alternative splicing, serotonin, serotonergic system, neuropsychiatric } \\
\text { disorders }\end{array}$ \\
\hline Abstract: & $\begin{array}{l}\text { BACKGROUND The serotonergic system is a key component of } \\
\text { physiological brain function and is essential for neurological proper } \\
\text { activity. Numerous neuropsychiatric disorders are associated with } \\
\text { deregulation of the serotonergic system. Accordingly, many } \\
\text { pharmacological treatments are focused on modulation of this system. } \\
\text { Whilst providing a promising line of therapeutic moderation, these } \\
\text { approaches may be complicated due to the presence of alternative } \\
\text { splicing events for key genes in this pathway. Alternative splicing is a co- } \\
\text { transcriptional process by which different mRNA transcripts can be } \\
\text { produced from the same gene. These different isoforms may have } \\
\text { diverse activities and functions and their relative balance is often critical } \\
\text { for the maintenance of homeostasis. Alternative splicing greatly } \\
\text { increases the production of proteins, augmenting cell plasticity and } \\
\text { provides an important control point for regulation of gene expression. } \\
\text { AIM The objective of this narrative review is to discuss the potential } \\
\text { impact of alternative splicing of different components of the serotonergic } \\
\text { system and speculate on their involvement in several neuropsychiatric } \\
\text { disorders. CONCLUSIONS The specific role of each isoform in disease and } \\
\text { their relative activities in the signalling pathways involved is yet to be } \\
\text { determined. We need to gain a better understanding the basis of } \\
\text { alternative isoforms of the serotonergic system in order to fully } \\
\text { understand their impact and be able to develop new effective } \\
\text { pharmacological isoform-specific targets. }\end{array}$ \\
\hline
\end{tabular}

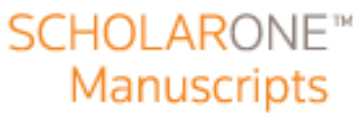




\title{
Alternative splicing on serotonergic system: implications in neuropsychiatric disorders
}

Eva Latorre ${ }^{1,3^{*}}$, Jose Emilio Mesonero ${ }^{2,3}$, Lorna W Harries ${ }^{1}$

\begin{abstract}
Affiliations
${ }^{1}$ Institute of Biomedical and Clinical Sciences, University of Exeter Medical School, University of Exeter, UK

${ }^{2}$ Departamento Farmacología y Fisiología, Facultad de Veterinaria, Instituto de Investigación Sanitaria de Aragón (IIS Aragón), Universidad de Zaragoza, Zaragoza, Spain
\end{abstract}

${ }^{3}$ Instituto Agroalimentario de Aragón - IA2- (Universidad de Zaragoza - CITA), Zaragoza, Spain

${ }^{*}$ Corresponding and reprint author:

Dr. Eva Latorre

Department of Biochemistry and Molecular and Cell Biology

University of Zaragoza

Pedro Cerbuna 12,

50009, Zaragoza, Spain

evalatorre@unizar.es

ORCID: 0000-0002-5797-3909 


\begin{abstract}
BACKGROUND The serotonergic system is a key component of physiological brain function and is essential for neurological proper activity. Numerous neuropsychiatric disorders are associated with deregulation of the serotonergic system. Accordingly, many pharmacological treatments are focused on modulation of this system. Whilst providing a promising line of therapeutic moderation, these approaches may be complicated due to the presence of alternative splicing events for key genes in this pathway. Alternative splicing is a co-transcriptional process by which different mRNA transcripts can be produced from the same gene. These different isoforms may have diverse activities and functions and their relative balance is often critical for the maintenance of homeostasis. Alternative splicing greatly increases the production of proteins, augmenting cell plasticity and provides an important control point for regulation of gene expression. AIM The objective of this narrative review is to discuss the potential impact of alternative splicing of different components of the serotonergic system and speculate on their involvement in several neuropsychiatric disorders. CONCLUSIONS The specific role of each isoform in disease and their relative activities in the signalling pathways involved is yet to be determined. We need to gain a better understanding the basis of alternative isoforms of the serotonergic system in order to fully understand their impact and be able to develop new effective pharmacological isoform-specific targets.
\end{abstract}

Keywords: Alternative splicing, serotonin, serotonergic system, neuropsychiatric disorders 
Serotonin is one of the most important neurotransmitters that influence mental health. The development of selective serotonin reuptake inhibitors (SSRIs) illustrates the importance of the serotonergic system in the treatment of mental disorders. However, treatment with SSRIs for 5 to 8 weeks is required for remission, which only occurs in $30 \%$ of patients (Akil et al., 2018). The precise role of the serotonergic system in neuropsychiatric disorders remains elusive, even after decades of intensive research, falling in some cases to yield effective therapeutic management. Part of the explanation for this may be that therapeutic moderation of genes in this system may be complicated by the presence of alternative isoforms of key genes, which may influence treatment response. Differentially-expressed isoforms may be generated by alternative splicing. This process is a key regulator of gene expression, increasing transcriptomic and proteomic diversity and influencing cellular plasticity (Su et al., 2018). The existence of multiple isoforms for many components of the serotoninergic system greatly increases the complexity of the system. Thus, the role of alternative splicing and the impact of multiple isoforms of genes in the serotonergic system on neuropsychiatric disorders remains almost unexplored. The objective of this narrative review is to curate the available literature and produce a definitive assessment of current knowledge and assess the importance that these isoforms may have in the pathogenesis and treatment of numerous neuropsychiatric disorders. In this review, we discuss about the importance of alternative splicing and their impact on serotonergic system and function of their components as tryptophan hydroxylase-2, serotonin transporter, monoamine oxidase A and serotonin receptors.

\section{Alternative Splicing}


The correct regulation of gene expression is fundamental for the control of serotonergic function and is achieved through mechanisms such as alternative splicing. This is a co-transcriptional process, which allows the generation of multiple forms of mRNA transcript from a single coding unit and is emerging as an important control point for gene expression. In this process, exons (or even introns) can be either included or excluded from precursor-mRNA resulting in multiple mature mRNA variants (Kelemen et al., 2013) which if translated, result in different isoforms which may have antagonistic functions or differential temporal and/or spatial expression patterns, yielding enormous plasticity and adaptability to the cells (Wang et al., 2015).

This process is a crucial mechanism for gene regulation and for generating transcriptomic diversity. Recent estimates indicate that the expression of over $95 \%$ of human multi-exon genes involves alternative splicing (Black, 2003). Splicing is carried out by the spliceosome, a massive structure in which five small nuclear ribonucleoprotein particles and a large number of auxiliary proteins cooperate to accurately recognize the splice sites and catalyse the two steps of the splicing reaction (Wahl et al., 2009) (Figure 1). There are numerous modes of alternative splicing, but the most common is exon skipping. In this mode, a particular exon may be included in mRNA under some conditions or in particular tissues and omitted from the mRNA in others. Changes in exon exclusion, intron retention or the use of alternative splice sites have also been reported which can alter protein structure, localization, regulation or function (Kelemen et al., 2013). The final outcome of alternative splicing is mainly the translation of related but distinct protein variants, encoded by the same gene, but differing in sequence and therefore potentially in their biomolecular and cellular properties (Bindereif, 2015). Alternative splicing of 
mRNA can also act as a direct regulator of gene expression, by the inclusion of poison exons which include premature stop codons, which are substrates for degradation by nonsense-mediated decay (McGlincy and Smith, 2008).

DNA methylation was originally thought to only affect transcription; however, emerging evidence shows that it can also regulate alternative splicing (Zhu et al., 2018). Exons, and especially splice sites, have higher levels of DNA methylation, and the splicing of about $22 \%$ of alternative exons is regulated by DNA methylation (Gelfman and Ast, 2013). Different mechanisms convey DNA methylation information into the regulation of alternative splicing; the modulation of the elongation rate of RNA polymerase II, and the formation of a protein bridge by heterochromatin protein 1 that recruits splicing factors onto transcribed alternative exons (Lev Maor et al., 2015).

Regulation of alternative splicing is an intricate process whereby multiple cis- and trans-acting components work in a co-ordinated fashion, guide the functional coupling between transcription and splicing. Additional molecular features, such as chromatin structure, DNA methylation, RNA structure and alternative transcription initiation and termination, collaborate with these basic components to generate the transcriptomic diversity due to alternative mRNA processing. Tissue-specific RNA binding proteins and microRNAs can also coordinate and regulate alternative splicing patterns (Grabowski, 2011), regulating the balanced production of isoforms according to cell needs.

Alternative splicing is a major mechanism used to generate proteomic diversity in the brain. Proteins affected by alternative splicing may have unaltered function, altered function, or no function at all. Splicing that generates non-functional isoforms have a 
significant impact on susceptibility to and development of a range of diseases. Therefore, alternative splicing is known to be involved in the regulation of normal physiological functions as well as in numerous pathologies.

\section{Serotonergic system}

The serotonergic system plays an essential role in the physiological functions of the central nervous system and the dysregulation of serotonin homeostasis is implicated in many neuropsychiatric disorders as anxiety, migraine or depression (Gingrich and Hen, 2001). The serotonergic system is the target of numerous pharmacological treatments; triptans, tricyclic antidepressants, agonists and antagonists of serotonin receptors or selective serotonin reuptake inhibitors (SSRIs) are frequently utilised in the treatment of neuropsychiatric disorders. Understanding the regulation of different components of serotonergic system is therefore critical for insight into the diagnosis and treatments of neuropsychiatric disorders.

Serotonin or 5-hydroxytryptamine $(5-\mathrm{HT})$ is a critical monoamine neurotransmitter that plays a crucial role in the control of several brain function as mood, sleep or appetite (Pratelli and Pasqualetti, 2018) and is also related to measures of cognitive function, including memory and learning (Cowen and Sherwood, 2013). Raphe nuclei neurons are the principal source of $5-\mathrm{HT}$ in the brain, where $5-\mathrm{HT}$ is synthetized from the amino acid L-tryptophan, by the concerted action of two enzymes: tryptophan hydroxylase (TPH) and aromatic amino acid decarboxylase (AAAD). Once released, 5-HT triggers its regulatory effects by binding specific $5-\mathrm{HT}$ receptors. The activity of 5-HT also depends on its extracellular availability, which is mainly modulated by the specific serotonin transporter (SERT) which removes 
secreted 5-HT from extracellular medium when it is no longer required. Finally, internalized 5-HT can be enzymatically degraded by mono-amino oxidases (MAO) (Charnay and Leger, 2010). All these components together form the serotonergic system which is active throughout the body but has critical functions at the intestinal and central nervous levels. Neuronal serotonergic system is composed by an 'ON' system of production (represented by serotonergic neurons which express TPH2) and an 'OFF' system (represented by the SERT that uptakes 5-HT, expressed in the same neurons). The activity of 'ON' and 'OFF' systems determines the 5-HT levels, and therefore, 'ON' and 'OFF' balance regulates serotonergic effects. Finally, a great diversity of receptors drives the biological activity of the serotonergic signals through seven different receptor classes of serotonin receptors, classified as from 5-HTR1 to 5-HTR7. 5-HTR3 is a ligand gated ion channel, while the rest of the receptors belong to the G-protein coupled receptor family (Nichols and Nichols, 2008). As a result of the above, the effects of $5-\mathrm{HT}$ are wide, and sometimes divergent.

The regulation of serotonergic components expression is fundamental for homeostasis. A better understanding of the expression, activity and regulation of the serotonergic system is critical for the development of new therapies for neuropsychiatric disorders. Alternative splicing has been described for genes responsible for the synthesis, uptake and degradation of serotonin as well as for serotonin receptors; some alternatively expressed isoforms are known to impact neuropsychiatric pathologies or resistance to treatments (Table 1).

In this review we summarize the knowledge about alternative mRNA processing patterns of genes in the serotonergic system (tryptophan hydroxylase-2, serotonin transporter, monoamine oxidase $\mathrm{A}$ and serotonin receptors) and discuss their implications for neuropsychiatric disorders. We conclude that deregulated alternative 
splicing of the serotonergic system is implicated in the aetiology of neuropsychiatric diseases and in some cases may underpin resistance to treatment.

\section{Tryptophan hydroxylase-2}

Tryptophan hydroxylase-2 (TPH2) is the rate-limiting enzyme in brain 5-HT synthesis, and is a candidate gene for disruption of brain serotonergic homeostasis in neuropsychiatric disorders (Chen and Miller, 2013; Waider et al., 2011). Decreased 5-HT level have also been associated with vulnerability to suicidal behaviour; a complex trait influenced by genetic and environmental risk factors (Menon and Kattimani, 2015). The physiological impact of early life events on genes involved in stress response and the serotonergic system is thought to be mediated by epigenetic processes (Booij et al., 2013; Turecki et al., 2012). This may lead to neurobiological changes that contribute to developmental, emotional, cognitive and behavioural phenotypes, and consequently increase the risk for suicidal behaviour. TPH2 expression is increased in the dorsal raphe nucleus of suicidal individuals with depression (Bach-Mizrachi et al., 2008; Chen et al., 2017) and may act to compensate low 5-HT levels. Increased TPH2 mRNA expression has also been reported in response to early life stressful events in rodents (Hale et al., 2011), suggesting that adverse environmental stimuli may influence serotonin homeostasis. Although TPH2 overexpression may represent a compensatory mechanism for low serotonin levels (Bach-Mizrachi et al., 2008), it is known that TPH2 mRNAs undergo complex post-transcriptional processing (alternative splicing and RNA editing) to increase the variety of functionally different protein isoforms (Abumaria et al., 2008; Grohmann et al., 2010). 
Except for a few examples where functional characterization has been undertaken (Abumaria et al., 2008; Grohmann et al., 2010), the majority of human TPH2 genetic variants remain to be physiologically uncharacterized. TPH2 encodes two alternatively spliced variants, denoted $T P H 2 a$ and $T P H 2 b$, where TPH2b has higher activity than TPH2a. Both splice variants undergo dynamic RNA-editing in a mutually exclusive manner, suggesting a complex fine-tuning of central nervous system $5-\mathrm{HT}$ biosynthesis at the level of the RNA transcript (Grohmann et al., 2010). A truncated TPH2 protein (TPH2-TR) generated by alternative splicing and lacking enzyme activity has also been reported (Zhang et al., 2011). TPH2 intron 7 is highly polymorphic, containing several variants affecting the 3' splice site which may alter splicing efficiency (Kloiber et al., 2010). Most of the identified SNPs in TPH2 are located in the introns or promoter region and probably act by altering TPH2 transcription or disruption of splicing by alteration of cis-acting spicing regulatory elements.

Genetic analyses have indicated potential associations between variants in the TPH2 gene and neuropsychiatric disorders such as depression (Gao et al., 2012), bipolar disorder (Khanzada et al., 2017), suicidal behaviour (Pompili et al., 2017), autism (Egawa et al., 2013) and attention-deficit/hyperactivity disorder (Ottenhof et al., 2018). However, other studies in different cohorts report a lack of association with these disorders (Geissler et al., 2017; Pan et al., 2019). Discrepancies in such studies are difficult to reconcile, but not unexpected given the different cohorts used, the requirement for large sample numbers and limitations in diagnostic criteria. The specific involvement of $\mathrm{TPH} 2 \mathrm{a}$ and $\mathrm{TPH} 2 \mathrm{~b}$ isoforms in these disorders remains unexplored and may be differentially impacted by genetic variation. 


\section{Serotonin transporter}

Serotonin signalling is also regulated by the activity of the serotonin transporter (SERT, encoded by SLC6A4 gene) which uptakes extracellular 5-HT into the neurons (Chen et al., 2004). Selective serotonin-reuptake inhibitors (SSRIs) are common therapies for a variety of affective and anxiety disorders and are the most effective and used antidepressant drugs. Unfortunately, a large percentage of patients do not respond to initial therapy and a similarly large fraction experiences side effects (Vaswani et al., 2003). In the presence of SSRIs, 5-HT remains in the extracellular space longer, as SSRIs inhibit SERT activity, allowing prolonged activation of 5-HT receptors. Moreover, as SERT protein is identical in the brain and the gut, systemic SSRIs also affect $5-\mathrm{HT}$ signalling in the gut causing adverse gastrointestinal reactions (Grover and Camilleri, 2013).

The key physiological roles played by serotonin throughout the brain support the hypothesis that variations of SERT activity and/or expression might lead to changes in serotonergic signalling. Common variation in the promoter region of the SLC6A4 gene is associated with altered functional expression of SERT. A well-defined 44 base pair insertion/deletion polymorphism in this region leads to reduced expression of transporter. Several reports have identified associations between the presence of the variant and psychiatric conditions, including stress-associated depression (Peitl et al., 2017), alcohol dependence (Twitchell et al., 2001) or neuroticism (Greenberg et al., 2000; Twitchell et al., 2001). Altered SERT function could also play a key role in the pathogenesis of many neuropsychiatric disorders such as bipolar disorder (Chou et al., 2016), depression (Lira et al., 2003), autism (Tanaka et al., 2018), eating disorders (Tauscher et al., 2001) or anxiety (Maron et al., 2004), among others. Evidence suggests gene-by-environment interactions could be fundamental 
for SERT expression and their consequent implications in diseases (Caspi et al., 2003; Karg et al., 2011). Individuals who have been subject to child abuse demonstrate altered DNA methylation which may influence the expression of SERT spliced variants (Vijayendran et al., 2012). Altered CpG methylation within the promoter of SLC6A4 has been associated with early or recent exposure to psychosocial stress, and a number of neuropsychiatric disorders demonstrate an imbalance of SERT isoforms (Palma-Gudiel and Fananas, 2017). This indicates that stress-induced DNA methylation changes may impact the alternative splicing patterns of SLC6A4.

The SLC6A4 gene encodes several variants of exon-1 (1A, 1B and 1C). Alternative splicing yields two mRNA species comprising exons $1 A+2(S E R T-1 A)$ and $1 A+1 B+2$ (SERT-1AB). The transcription of both mRNAs is controlled by a promoter containing highly polymorphic sequences (Ozsarac et al., 2002) which has the potential to yield multiple SERT isoforms. A study of human intestine has revealed the existence of three SERT mRNA species (SERT-1A, SERT-1AB and SERT-1C) (Gill et al., 2008). The distinct transcriptional start site and alternate promoters suggest that intestinal SERT could potentially be differentially regulated compared with brain SERT. This raises the possibility of site-specific therapeutics for SERT regulation in the treatment of multiple disorders which may have efficacy without the associated side effects. Spliced SERT isoforms may also impact 5-HT availability during SSRIs treatment and alter drug efficacy and risk of adverse reactions.

It is also important to note that SERT may undergo other post-translational changes which could impact their activity. Studies using in vivo and in vitro model systems have demonstrated that post-translational modifications, including phosphorylation, glycosylation, serotonylation, and disulfide bond formation, all of which favourably 
influence SERT conformation and allow the transporter to function most efficiently (Cooper et al., 2019).

\section{Monoamino Oxidase A Enzyme}

Once $5-\mathrm{HT}$ is taken up by SERT, $5-\mathrm{HT}$ can be degraded by MAO-A (monoamine oxidase A). This enzyme plays a vital role in the deamination of dietary monoamines and neurotransmitters as 5-HT (Gaweska and Fitzpatrick, 2011). Abnormal MAO-A activity has been reported in several neuropsychiatric disorders, including schizophrenia (Sun et al., 2012), depression (Rivera et al., 2009) or Alzheimer's disease (Takehashi et al., 2002) and MAO inhibitors are used as an effective treatment for depression (Thomas et al., 2015). Moreover, some MAO-A polymorphisms have been related with aggressive behaviour (Frau et al., 2019; Xiang et al., 2019).

MAO-A can be alternative spliced, creating a less efficient isoform (Biondo, 2017). The spliced isoform (MAO-A short) excludes the exon 14 generating a frameshift mutation that results in a premature stop codon in exon 15. This variant encodes for a truncated protein in the transmembrane domain which loses the enzymatic activity.

Although serotonin is metabolized by MAO-A, the predominant enzyme in the dorsal raphe nucleus is MAO-B (Arai et al., 1997). Other functional MAOs exist but may act on other neurotransmitters as phenylethylamine, dopamine or benzylamine (Gaweska and Fitzpatrick, 2011). Increased MAO-B mRNA levels have been related to Parkinson disease and dementia (Mallajosyula et al., 2008) and similarly to MAOA, some spliced isoforms for MAO-B have been also described (Jakubauskiene et al., 2012). 
MAOs have been implicated in the pathogenesis of Alzheimer's disease, and may influence the formation of amyloid plaques and neurofibrillary tangles resulting in cognitive impairment. Several studies have indicated that MAO inhibitors might improve cognitive deficits and reverse amyloid $A \beta$ pathology. Thus, MAO inhibitors may have promise as future therapeutic agents for Alzheimer's disease (Cai, 2014). A better understanding of MAO alterative spliced isoforms would be necessary to realise this aim.

\section{Serotonin Receptors}

Eighteen different genes encode serotonin receptor family members (Molderings, 2012). Whilst five genes belonging to the 5-HTR1 class and two from the 5-HTR5 class do not demonstrate alternative splicing, alternative isoforms have been reported for. 5-HTR2 (De Lucchini et al., 2001), 5-HTR3 (Bruss et al., 2000), 5-HTR4 (Bender et al., 2000), 5-HTR6 (Olsen et al., 1999) and 5-HTR7 (Gellynck et al., 2008) in various organisms, including humans.

The $5-\mathrm{HT}_{1 \mathrm{~A}}$ receptor is the most widespread of all $5-\mathrm{HT}$ receptors and its expression is related with anxiety and major depression (Garcia-Garcia et al., 2014). In the central nervous system, the $5-\mathrm{HT}_{1 \mathrm{~A}}$ receptor is expressed in the cerebral cortex, hippocampus, amygdala and raphe nuclei in higher density, while low amounts also are found in the basal ganglia and the thalamus. The 5-HT1A gene, originally thought to be intronless, is now known to undergo alternatively splicing in its 3 '-UTR region, yielding two novel splice variants (Le Francois et al., 2018). This results in the removal of a miR135 binding site, which stabilises 5-HT1A RNA and increases 5$\mathrm{HT}_{1 \mathrm{~A}}$ expression. The spliced variants are extremely stable compared with the 
unspliced version that is rapidly degraded, consistent with destabilization induced by miR-135 (Issler et al., 2014). The spliced 5-HT $1 \mathrm{~A}$ variants were also seen to be reduced in individuals with major depression in a genotype-dependent manner (Albert et al., 2019).

\section{Serotonin receptor $2\left(5-\mathrm{HT}_{2}\right)$}

The 5- $\mathrm{HT}_{2}$ receptor subfamily comprises a group of excitatory, primarily postsynaptic, G-protein-coupled receptors, which bring about their effects via stimulation of phospholipase $C$. This subfamily contains three receptors $(2 A, 2 B$ and 2C) which are functionally linked to promote release of intracellular $\mathrm{Ca}^{2+}$. Their pharmacological significance is substantial due to both the clinical importance and complex pharmacological features of these receptors.

Receptor $2 \mathrm{~A}\left(5-\mathrm{HT}_{2 \mathrm{~A}}\right)$ is abundantly expressed on pyramidal cells and interneurons in the prefrontal cortex, where it regulates the balance between excitatory and inhibitory responses (Puig and Gulledge, 2011). Many studies have demonstrated that serotonin signalling from dorsal raphe to the prefrontal cortex are involved in cognitive behaviour, with 5- $\mathrm{HT}_{2 \mathrm{~A}}$ being crucial for serotonergic signalling (Zhang and Stackman, 2015). In addition, 5- $\mathrm{HT}_{2 \mathrm{~A}}$ is also highly expressed in limbic neurocircuitry and has been strongly implicated in the regulation of anxiety-like behaviour (Ghasemi et al., 2018; Weisstaub et al., 2006).

The HTR2A gene expresses up to 10 distinct sense-encoded exons generated through alternative splicing, generating at least 8 protein isoforms of HTR2A (Ruble et al., 2016). Another HTR2A isoform exists, which includes an $118 \mathrm{bp}$ insertion that produces a premature stop codon, resulting in a truncated and inactivated protein 
(Guest et al., 2000). Although this variant lacks the structural domains involved with ligand and intracellular signalling, it could regulate the function of native serotonin receptors on their synthesis, protein-ligand interactions or intracellular trafficking. Patients with schizophrenia exhibit reduced cortical $5-\mathrm{HT}_{2 \mathrm{~A}}$ activity, but it is as yet unclear whether this reduction might result from medication (Abi-Dargham, 2007). Many schizophrenia patients carry a genetic variant (rs6314) which has potential to alter the alternative splicing pattern of HTR2A gene (Blasi et al., 2013). As SERT and $\mathrm{TPH} 2,5-\mathrm{HT}_{2 \mathrm{~A}}$ can also be regulated by DNA methylation, which has been shown to affect the balance of isoforms in schizophrenia (Cheah et al., 2017). An imbalance of $H T R 2 A$ isoforms has also been suggested to impair working memory and attenuate improvement after olanzapine $\left(5-\mathrm{HT}_{2 \mathrm{~A}}\right.$ antagonist) treatment (Blasi et al., 2013).

The physiological role of the serotonin receptor $2 \mathrm{~B}\left(5-\mathrm{HT}_{2 \mathrm{~B}}\right)$ is not yet fully understood. Several animal studies have suggested that $5-\mathrm{HT}_{2 \mathrm{~B}}$ receptor mediates the embryonic morphogenesis (Nebigil et al., 2000) and its activation causes anxiety and reduced grooming in mice (Duxon et al., 1997). It has also been described as a pharmacological candidate gene for early-onset obsessive-compulsive disorder (Kim et al., 2000; de Leeuw and Westenberg, 2008). The HTR2B gene has 4 spliced regions extending at least 100 base pairs beyond each exon-intron boundary. The isoforms are currently poorly characterised (Kim et al., 2000), but an alternative isoform has been reported (Bonhaus et al., 1995). Potential associations have been suggested between the $5-\mathrm{HT}_{2 \mathrm{~B}}$ receptor and migraine that may explain the efficacy of methysergide and cyproheptadine $\left(5-\mathrm{HT}_{2 \mathrm{~B}}\right.$ antagonists) for migraine prophylaxis (Segelcke and Messlinger, 2017). 
The serotonin receptor $2 \mathrm{C}\left(5-\mathrm{HT}_{2 \mathrm{C}}\right)$ controls key physiological functions, such as food intake, anxiety, sleep and motor neuron activity (Heisler et al., 2007; Monti, 2011). Deregulation of $5-\mathrm{HT}_{2 \mathrm{C}}$ receptors activity has been described in depression (Martin et al., 2014), schizophrenia (Castensson et al., 2005), suicidal behaviour (Gurevich et al., 2002), and spinal cord injury (Murray et al., 2010) in humans as well as in mouse models of obesity (Schellekens et al., 2012). Many antipsychotic drugs used to treat depression, anxiety, and schizophrenic disorders are known to interact with the $5-\mathrm{HT}_{2 \mathrm{C}}$ receptors, which may contributes to the drug efficacy (Chagraoui et al., 2016; Martin et al., 2014). The HTR2C gene is mainly regulated by pre-mRNA processing. The HTR2C gene generates at least 33 mRNA isoforms encoding 25 proteins through alternative splicing and RNA editing (Stamm et al., 2017), which has effects on constitutive activity as well as alternative splicing. A truncated isoform (5- $\left.\mathrm{HT}_{2 \mathrm{C} \_} \mathrm{tr}\right)$ has also been reported with an attenuate activity through heterodimerization (Martin et al., 2013; Zhang et al., 2016). Increased levels of 5$\mathrm{HT}_{2 \mathrm{C} \_} \mathrm{tr}$ isoform have also been reported in the hypothalamus of mice with PraderWilli Syndrome (PWS), an imprinting disorder resulting in altered serotonin and satiety responses (Garfield et al., 2016). Editing of the HTR2C gene is highly dynamic and changes under both physiological and pathological challenge, such as water maze learning (Du et al., 2007), obesity (Schellekens et al., 2012) or spinal cord injury (Di Narzo et al., 2014). This has potential to generate $5-\mathrm{HT}_{2 \mathrm{C}}$ isoforms with different signalling properties. Moreover, it evidence suggests that the balance of 5 -HT2c isoforms is critical in neuronal differentiation; changing the predominant isoform upon neuronal commitment, favours production of full-length receptor isoforms with higher activity (Bratkovic et al., 2018). 


\section{Serotonin receptor $3\left(5-\mathrm{HT}_{3}\right)$}

$5-\mathrm{HT}_{3}$ is a well-known $5-\mathrm{HT}$ receptor in the gut where is involved in the regulation of intestinal motility (De Ponti and Tonini, 2001), nausea and vomiting (Endo et al., 2000). $5-\mathrm{HT}_{3}$ is also present in central nervous system, specifically in the hippocampus, amygdala and spinal cord (Chameau and van Hooft, 2006), but its exact role is still not fully understood. The treatment with $5-\mathrm{HT}_{3}$ antagonists in animal models has shown psychotropic effects and improvement of cognitive function (Costall and Naylor, 2004).

5- $\mathrm{HT}_{3}$ belongs to the Cys-loop superfamily of ligand-gated ion channel, and therefore differs structurally and functionally from other 5-HT receptors which are G proteincoupled receptors. A functional channel may be composed by five identical $5-\mathrm{HT}_{3 \mathrm{~A}}$ subunits (monopentameric) or a mixture of $5-\mathrm{HT}_{3 \mathrm{~A}}$ and one of $5-\mathrm{HT}_{3 \mathrm{~B}}$ (heteropentameric). The existence of two alternative promoters in the HTR3B gene that codes for the B-subunit have been reported. The alternative promoters demonstrate tissue specificity, as the canonical transcript could be detected in gut, while the alternative transcript was only detected in brain (Tzvetkov et al., 2007). Similarly, the HTR3A gene is expressed as two splice isoforms (short and long variants) which are differentially regulated in vivo. The additional six amino acids in the long form may change the structure in such a way as to prevent or allow access of appropriate enzymes, resulting in differential phosphorylation levels (Hubbard et al., 2000). 5- $\mathrm{HT}_{3}$ antagonists have been extensively used to treat chemotherapyinduced emesis and diarrhoea-predominant irritable bowel syndrome and have a significantly slowing effect on gastrointestinal transit. However, there are few side effects related to the use of $5-\mathrm{HT}_{3}$ antagonists; the most common are headache and dizziness. Moreover, 5-HT3 antagonists seem to be a feature of new antidepressant 
drugs such as vortioxetine. As $5-\mathrm{HT}_{3}$ isoforms seem to be tissue-specific, the development of isoform-specific antagonists may help ameliorate side effects.

\section{Serotonin receptor $4\left(5-\mathrm{HT}_{4}\right)$}

$5-\mathrm{HT}_{4}$ is involved in cognitive function and memory consolidation. This receptor serves as a potential target for the development of therapeutic agents implicated in neurological disorders including Alzheimer's disease (Maillet et al., 2004), anorexia nervosa (Jean et al., 2007), anxiety (Bockaert et al., 2004) and depression (Lucas et al., 2007). The absence of 5- $\mathrm{HT}_{4}$ also modulates depression- and anxiety-responses in mice (Amigo et al., 2016) and SSRI treatment under pathological depression appear to be critically dependent on $5-\mathrm{HT}_{4}$ (Mendez-David et al., 2014).

At least 11 human $5-\mathrm{HT}_{4}$ splice variants have been reported to date (Rebholz et al., 2018). The HTR4 gene undergoes alternative splicing at its C-terminus to produce 4 variants; $A$ and $B$ are abundantly expressed in brain, whilst $C$ and $D$ are entericspecific (Liu et al., 2009). Isoforms A and B show differences in ligand binding, signal transduction and pharmacological patterns, and differential response to drugs (Pindon et al., 2002). A study has also identified 4 new variants in the $\mathrm{N}$-terminus of the HTR4 gene (Azim et al., 2012) in mouse brain designated as T1, T2I, T2s, and T3. All variants differ in their first two exons making a unique N-termini for HTR4 variants, giving them different properties in terms of acetylation, N-glycosylation, phosphorylation and their consequent functionally repercussions. Given the variety of HTR4 isoforms, the pharmacological characterisation of the spliced variants is necessary to understand the implicated mechanisms and develop adequate effective 
treatments (Brattelid et al., 2004). To date, no specific isoform has been linked to neuropsychiatric disorders; however, interactions cannot be discarded.

\section{Serotonin receptor $6\left(5-\mathrm{HT}_{6}\right)$}

$5-\mathrm{HT}_{6}$ is found in the limbic and extrapyramidal areas of the brain, supporting the suggestion that this receptor may be involved in the mechanism of action of antipsychotics (Morozova et al., 2017). Pharmacological studies have demonstrated that atypical antipsychotic drugs have high affinity for this receptor and its mRNA expression is altered in schizophrenia patients, suggesting it may hold promise as a potential therapeutic target for schizophrenia (East et al., 2002). Some 5-HT6 antagonists have shown efficacy in animal models for cognitive impairment in multiple cognitive domains relevant for schizophrenia (de Bruin and Kruse, 2015). Moreover, during the last decade, $5-\mathrm{HT}_{6}$ receptor has received increasing attention and become a promising target for improving cognition. Some 5- $\mathrm{HT}_{6}$-targeted compounds have been suggested as powerful drug candidates for the treatment of Alzheimer's disease (Ramirez, 2013).

To date, only one spliced isoform has been described for HTR6, generated by a 289 bp deletion. This isoform encodes a receptor which possesses only the first three transmembrane domains and exhibits a different expression pattern, being detected only in caudate and substantia nigra, while the canonical transcript was located in cortex, hippocampus, cerebellum, thalamus, caudate and substantia nigra (Olsen et al., 1999). The spliced isoform is expressed in the cell membrane; however its ability to fold properly and form the correct ligand binding site seems unlikely. Tissue specific regulation of alternatively spliced transcripts may provide a by which 
specialized cells can generate different proteins in response to environmental challenges (Porazinski and Ladomery, 2018). More studies are needed to develop a therapeutic therapy based in $5-\mathrm{HT}_{6}$ isoforms.

Apart from $5-\mathrm{HT}_{6}$ spliced isoform, this receptor could play a role in regulating alternative splicing of other important genes. In fact, a recent study has described the interaction between $5-\mathrm{HT}_{6}$ and Nova-1, a brain-enriched splicing regulator of proteins involved in synapse formation or synaptic transmission, including inhibitory GABA receptors. In particular, the overexpression of $5-\mathrm{HT}_{6}$ reduces the splicing activity of Nova-1, and contrast, overexpression of Nova-1 weakens the activity and stability of 5- $\mathrm{HT}_{6}$ via promoting proteasomal degradation (Kim et al., 2019).

\section{Serotonin receptor $7\left(5-\mathrm{HT}_{7}\right)$}

The $5-\mathrm{HT}_{7}$ receptor is one of the most recently identified members of the serotonin receptor family. The physiological role for the $5-\mathrm{HT}_{7}$ receptor within the central nervous has been clearly established in regulation of circadian rhythm (Glass et al., 2003) and in thermoregulation (Hedlund et al., 2004) as well as in learning and memory (Meneses, 2014). Other biological functions including moderation of the effects of atypical neuroleptics (Manfra et al., 2015) and antidepressants (Sarkisyan et al., 2010) or participation in pain and inflammatory pathways (Rocha-Gonzalez et al., 2005) have also been related to $5-\mathrm{HT}_{7}$ receptor activity. Selective $5-\mathrm{HT}_{7}$ receptor ligands may therefore have potential therapeutic applications for the treatment of pain and migraine, schizophrenia, anxiety, cognitive disturbances and inflammation. However, it is critical to know in depth the differences of $5-\mathrm{HT}_{7}$ isoforms and develop isoforms-specific ligands. 
Four HTR7 splice variants, (a, b, c, and d) have been described in human and rat tissues. These variants differ in their carboxyl terminal as a consequence of alternative splicing (Guthrie et al., 2005). Two of these, (a and b) are conserved in rat and human. An additional form, $5-\mathrm{HT}_{7 \mathrm{c}}$ is expressed only in rat tissues, whereas HTR7d is expressed only in humans. All of the isoforms appear to be functionally active and have similar agonist binding characteristics (Krobert and Levy, 2002), but the distribution of expression of the receptor isoforms is different in several brain regions and peripheral tissues (Krobert et al., 2001). Differences in pharmacology have also been described; The HTR7d isoform exhibits receptor trafficking that is distinct from HTR7a or HTR7b, whereas human HTR7d receptors display agonistindependent internalization with internalization noted even in the presence of antagonist (Guthrie et al., 2005). Improved characterisation of HTR7 isoforms is required to fully explore their implications in neuropsychiatric diseases.

\section{Conclusions}

Transcriptome profiling in human tissues has greatly increased our appreciation of the diversity of RNA isoforms, revealing that alternative splicing is a key mechanism for gene regulation. Alternative splicing creates transcriptomic and proteomic diversity and cellular plasticity and plays a critical role in the development of many diseases. Identification of specific isoforms that are dysregulated in diseases raise the possibility developing tailored therapeutics which could be successfully harnessed in the clinic (Havens et al., 2013).

Alternative splicing plays a key role in regulating the activity of the serotonergic system, increasing the complexity of the system, with the presence of tissue specific 
isoforms and diversity in phosphorylation levels and intracellular trafficking. As the Figure 2 shows, the 5-HT levels are controlled by the activity of TPH2, SERT and MAO-A with at least, 7 different isoforms from the three genes. The combination of those spliced isoforms would generate numerous scenarios where 5-HT levels could be differently regulated. In addition to those 5-HT controlling-isoforms, alternative splicing increases hugely the variety of 5-HT receptors, being a clear example the 33 spliced isoforms for $5-\mathrm{HT}_{2 \mathrm{C}}$. The numerous spliced variant receptors present differences in their activity, expression, regulation, structure and sensitivities to ligands. Hence the need of in-depth characterization of spliced isoforms and development of isoform-specific targets are required for a better treatment of neuropsychiatric disorders.

The serotonergic system has been implicated in numerous neuropsychiatric disorders and the existence of different serotonergic isoforms could therefore play a critical role in susceptibility, disease development or the incidence of side effects, as well as representing future potential therapeutic targets. Recent studies plead for therapeutic approaches on alternative splicing (Harries, 2019; Lipscombe and Lopez Soto, 2019).

This is exemplified by the HTR2C gene, comprises a good candidate for RNA therapy for multiple neuropsychiatric disorders. The ratio between truncated and canonical receptors could be manipulated through antisense oligonucleotides (AONs), allowing selective modulation of $5-\mathrm{HT}_{2 \mathrm{C}}$ receptor activity. The production of an attenuated splice variant may allow regulation the activity of the $5-\mathrm{HT}_{2 \mathrm{C}}$ receptor. This could prove useful for future treatment of disorders such as hyperphagia, as demonstrated by the promising results reported for Prader-Willi syndrome (Zhang et al., 2016). A more in-depth characterization of spliced isoforms from genes 
underpinning the serotonergic system and assessment of their involvement in human pathology is merited. It is also important to note, that much of our knowledge about the function of splice isoforms comes from cell culture techniques; validation in vivo is therefore an important pre-requisite for clinical targeting important candidate genes. Serotonergic components are, in many cases, coding by large genes multiple introns and exons. The limited exploration of the splicing events in the serotonergic system genes probably does not capture the extent of spliced isoforms and a fine characterization of serotonergic isoforms is critically needed. The exact role of each isoform in disease and their relative activities in the signalling pathways involved is also yet to be determined in order to fully understand their impact. Although it has been shown that some splice variants have different sensitivities to ligands, it has only been demonstrated with a small number of agonists. It remains a considerable challenge to identify and develop splice variant-selective drugs.

Therefore, we need to gain a better understanding the basis of alternative isoforms of the serotonergic system to develop new effective pharmacological isoform-specific targets. The advanced knowledge of spliced isoforms will also enable us to adapt the best treatment for each patient to the different pathologies related to neuropsychiatric disorders linked to the serotonergic system.

\section{Declaration of interest}

The authors report no competing interests.

\section{Funding}


This work was generously supported by Dunhill Medical Trust (R386/114).

1

2

4

5

6

7

8

10

11

12

13

14

15

16

17

18

19

20

21

22

23

24

25

26

27

28

29

30

31

32

33

34

35

36

37

38

39

40

41

42

43

44

45

46

47

48

49

50

51

52

53

54

55

56

57

58

59

60 


\section{REFERENCES}

Abi-Dargham A. (2007) Alterations of serotonin transmission in schizophrenia. Int Rev Neurobiol 78: 133-164.

Abumaria N, Ribic A, Anacker C, et al. (2008) Stress upregulates TPH1 but not TPH2 mRNA in the rat dorsal raphe nucleus: identification of two TPH2 mRNA splice variants. Cell Mol Neurobiol 28: 331-342.

Akil H, Gordon J, Hen R, et al. (2018) Treatment resistant depression: A multi-scale, systems biology approach. Neurosci Biobehav Rev 84: 272-288.

Albert PR, Le Francois B and Vahid-Ansari F. (2019) Genetic, epigenetic and posttranscriptional mechanisms for treatment of major depression: the 5-HT1A receptor gene as a paradigm. $J$ Psychiatry Neurosci 44: 1-13.

Amigo J, Diaz A, Pilar-Cuellar F, et al. (2016) The absence of 5-HT4 receptors modulates depressionand anxiety-like responses and influences the response of fluoxetine in olfactory bulbectomised mice: Adaptive changes in hippocampal neuroplasticity markers and 5-HT1A autoreceptor. Neuropharmacology 111: 47-58.

Arai R, Kimura H, Nagatsu I, et al. (1997) Preferential localization of monoamine oxidase type A activity in neurons of the locus coeruleus and type $B$ activity in neurons of the dorsal raphe nucleus of the rat: a detailed enzyme histochemical study. Brain Res 745: 352-356.

Azim S, Banday AR and Tabish M. (2012) Identification of alternatively spliced multiple transcripts of 5-hydroxytryptamine receptor in mouse. Brain Res Bull 87: 250-258.

Bach-Mizrachi H, Underwood MD, Tin A, et al. (2008) Elevated expression of tryptophan hydroxylase-2 mRNA at the neuronal level in the dorsal and median raphe nuclei of depressed suicides. Mol Psychiatry 13: 507-513, 465.

Bender E, Pindon A, van Oers I, et al. (2000) Structure of the human serotonin 5-HT4 receptor gene and cloning of a novel 5-HT4 splice variant. J Neurochem 74: 478-489.

Bindereif A. (2015) Pre-mRNA splicing: from protein-coding to noncoding RNAs. RNA 21: 571-572.

Biondo A. (2017) Modulating Alternative Splicing of MAO-A Gene Transcript. Available at: http://www.biotechniques.org/students/2017/alyssa/paper.

Black DL. (2003) Mechanisms of alternative pre-messenger RNA splicing. Annu Rev Biochem 72: 291336.

Blasi G, De Virgilio C, Papazacharias A, et al. (2013) Converging evidence for the association of functional genetic variation in the serotonin receptor $2 a$ gene with prefrontal function and olanzapine treatment. JAMA Psychiatry 70: 921-930.

Bockaert J, Claeysen S, Compan V, et al. (2004) 5-HT4 receptors. Curr Drug Targets CNS Neurol Disord 3: 39-51.

Bonhaus DW, Bach C, DeSouza A, et al. (1995) The pharmacology and distribution of human 5hydroxytryptamine2B (5-HT2B) receptor gene products: comparison with 5-HT2A and 5HT2C receptors. Br J Pharmacol 115: 622-628.

Booij L, Wang D, Levesque ML, et al. (2013) Looking beyond the DNA sequence: the relevance of DNA methylation processes for the stress-diathesis model of depression. Philos Trans $R$ Soc Lond B Biol Sci 368: 20120251.

Bratkovic T, Modic M, Camargo Ortega G, et al. (2018) Neuronal differentiation induces SNORD115 expression and is accompanied by post-transcriptional changes of serotonin receptor 2c mRNA. Sci Rep 8: 5101.

Brattelid T, Kvingedal AM, Krobert KA, et al. (2004) Cloning, pharmacological characterisation and tissue distribution of a novel 5-HT4 receptor splice variant, 5-HT4(i). Naunyn Schmiedebergs Arch Pharmacol 369: 616-628.

Bruss M, Barann M, Hayer-Zillgen M, et al. (2000) Modified 5-HT3A receptor function by coexpression of alternatively spliced human 5-HT3A receptor isoforms. Naunyn Schmiedebergs Arch Pharmacol 362: 392-401. 
Cai Z. (2014) Monoamine oxidase inhibitors: promising therapeutic agents for Alzheimer's disease (Review). Mol Med Rep 9: 1533-1541.

Caspi A, Sugden K, Moffitt TE, et al. (2003) Influence of life stress on depression: moderation by a polymorphism in the 5-HTT gene. Science 301: 386-389.

Castensson A, Aberg K, McCarthy S, et al. (2005) Serotonin receptor 2C (HTR2C) and schizophrenia: examination of possible medication and genetic influences on expression levels. Am J Med Genet B Neuropsychiatr Genet 134B: 84-89.

Cooper A, Woulfe D and Kilic F. (2019) Post-translational modifications of serotonin transporter. Pharmacol Res 140: 7-13.

Costall B and Naylor RJ. (2004) 5-HT3 receptors. Curr Drug Targets CNS Neurol Disord 3: 27-37.

Cowen P and Sherwood AC. (2013) The role of serotonin in cognitive function: evidence from recent studies and implications for understanding depression. J Psychopharmacol 27: 575-583.

Chagraoui A, Thibaut F, Skiba M, et al. (2016) 5-HT2C receptors in psychiatric disorders: A review. Prog Neuropsychopharmacol Biol Psychiatry 66: 120-135.

Chameau P and van Hooft JA. (2006) Serotonin 5-HT(3) receptors in the central nervous system. Cell Tissue Res 326: 573-581.

Charnay Y and Leger L. (2010) Brain serotonergic circuitries. Dialogues Clin Neurosci 12: 471-487.

Cheah SY, Lawford BR, Young RM, et al. (2017) mRNA Expression and DNA Methylation Analysis of Serotonin Receptor 2A (HTR2A) in the Human Schizophrenic Brain. Genes (Basel) 8.

Chen GL and Miller GM. (2013) Tryptophan hydroxylase-2: an emerging therapeutic target for stress disorders. Biochem Pharmacol 85: 1227-1233.

Chen NH, Reith ME and Quick MW. (2004) Synaptic uptake and beyond: the sodium- and chloridedependent neurotransmitter transporter family SLC6. Pflugers Arch 447: 519-531.

Chen Y, Xu H, Zhu M, et al. (2017) Stress inhibits tryptophan hydroxylase expression in a rat model of depression. Oncotarget 8: 63247-63257.

Chou YH, Hsieh WC, Chen LC, et al. (2016) Association between the serotonin transporter and cytokines: Implications for the pathophysiology of bipolar disorder. J Affect Disord 191: 2935.

de Bruin NM and Kruse CG. (2015) 5-HT6 Receptor Antagonists: Potential Efficacy for the Treatment of Cognitive Impairment in Schizophrenia. Curr Pharm Des 21: 3739-3759.

de Leeuw AS and Westenberg HG. (2008) Hypersensitivity of 5-HT2 receptors in OCD patients. An increased prolactin response after a challenge with meta-chlorophenylpiperazine and pretreatment with ritanserin and placebo. J Psychiatr Res 42: 894-901.

De Lucchini S, Marracci S and Nardi I. (2001) The serotonin 5-HT2B receptor from the puffer fish Tetraodon fluviatilis: cDNA cloning, genomic organization and alternatively spliced variants. Brain Res Mol Brain Res 97: 89-93.

De Ponti F and Tonini M. (2001) Irritable bowel syndrome: new agents targeting serotonin receptor subtypes. Drugs 61: 317-332.

Di Narzo AF, Kozlenkov A, Roussos P, et al. (2014) A unique gene expression signature associated with serotonin $2 \mathrm{C}$ receptor RNA editing in the prefrontal cortex and altered in suicide. Hum Mol Genet 23: 4801-4813.

Du Y, Stasko M, Costa AC, et al. (2007) Editing of the serotonin 2C receptor pre-mRNA: Effects of the Morris Water Maze. Gene 391: 186-197.

Duxon MS, Kennett GA, Lightowler S, et al. (1997) Activation of 5-HT2B receptors in the medial amygdala causes anxiolysis in the social interaction test in the rat. Neuropharmacology 36: 601-608.

East SZ, Burnet PW, Leslie RA, et al. (2002) 5-HT6 receptor binding sites in schizophrenia and following antipsychotic drug administration: autoradiographic studies with [125I]SB-258585. Synapse 45: 191-199. 
Egawa J, Watanabe Y, Endo T, et al. (2013) Association of rs2129575 in the tryptophan hydroxylase 2 gene with clinical phenotypes of autism spectrum disorders. Psychiatry Clin Neurosci 67: 457-458.

Endo T, Minami M, Hirafuji M, et al. (2000) Neurochemistry and neuropharmacology of emesis - the role of serotonin. Toxicology 153: 189-201.

Frau R, Fanni S, Serra V, et al. (2019) Dysfunctional mesocortical dopamine circuit at pre-adolescence is associated to aggressive behavior in MAO-A hypomorphic mice exposed to early life stress. Neuropharmacology.

Gao J, Pan Z, Jiao Z, et al. (2012) TPH2 gene polymorphisms and major depression--a meta-analysis. PLoS One 7: e36721.

Garcia-Garcia AL, Newman-Tancredi A and Leonardo ED. (2014) 5-HT(1A) [corrected] receptors in mood and anxiety: recent insights into autoreceptor versus heteroreceptor function. Psychopharmacology (Berl) 231: 623-636.

Garfield AS, Davies JR, Burke LK, et al. (2016) Increased alternate splicing of Htr2c in a mouse model for Prader-Willi syndrome leads disruption of $5 \mathrm{HT} 2 \mathrm{C}$ receptor mediated appetite. Mol Brain 9: 95.

Gaweska H and Fitzpatrick PF. (2011) Structures and Mechanism of the Monoamine Oxidase Family. Biomol Concepts 2: 365-377.

Geissler JM, Romanos M, Gerlach M, et al. (2017) No genetic association between attentiondeficit/hyperactivity disorder (ADHD) and Parkinson's disease in nine ADHD candidate SNPs. Atten Defic Hyperact Disord 9: 121-127.

Gelfman S and Ast G. (2013) When epigenetics meets alternative splicing: the roles of DNA methylation and GC architecture. Epigenomics 5: 351-353.

Gellynck E, Laenen K, Andressen KW, et al. (2008) Cloning, genomic organization and functionality of 5-HT(7) receptor splice variants from mouse brain. Gene 426: 23-31.

Ghasemi A, Seifi M, Baybordi F, et al. (2018) Association between serotonin 2A receptor genetic variations, stressful life events and suicide. Gene 658: 191-197.

Gill RK, Pant N, Saksena S, et al. (2008) Function, expression, and characterization of the serotonin transporter in the native human intestine. Am J Physiol Gastrointest Liver Physiol 294: G254262.

Gingrich JA and Hen R. (2001) Dissecting the role of the serotonin system in neuropsychiatric disorders using knockout mice. Psychopharmacology (Berl) 155: 1-10.

Glass JD, Grossman GH, Farnbauch L, et al. (2003) Midbrain raphe modulation of nonphotic circadian clock resetting and 5-HT release in the mammalian suprachiasmatic nucleus. $J$ Neurosci 23: 7451-7460.

Grabowski P. (2011) Alternative splicing takes shape during neuronal development. Curr Opin Genet Dev 21: 388-394.

Greenberg BD, Li Q, Lucas FR, et al. (2000) Association between the serotonin transporter promoter polymorphism and personality traits in a primarily female population sample. Am J Med Genet 96: 202-216.

Grohmann M, Hammer P, Walther M, et al. (2010) Alternative splicing and extensive RNA editing of human TPH2 transcripts. PLoS One 5: e8956.

Grover M and Camilleri M. (2013) Effects on gastrointestinal functions and symptoms of serotonergic psychoactive agents used in functional gastrointestinal diseases. J Gastroenterol 48: 177-181.

Guest PC, Salim K, Skynner HA, et al. (2000) Identification and characterization of a truncated variant of the 5-hydroxytryptamine(2A) receptor produced by alternative splicing. Brain Res 876: 238-244.

Gurevich I, Englander MT, Adlersberg M, et al. (2002) Modulation of serotonin 2C receptor editing by sustained changes in serotonergic neurotransmission. J Neurosci 22: 10529-10532. 
Guthrie CR, Murray AT, Franklin AA, et al. (2005) Differential agonist-mediated internalization of the human 5-hydroxytryptamine 7 receptor isoforms. J Pharmacol Exp Ther 313: 1003-1010.

Hale MW, Shekhar A and Lowry CA. (2011) Development by environment interactions controlling tryptophan hydroxylase expression. J Chem Neuroanat 41: 219-226.

Harries LW. (2019) RNA Biology Provides New Therapeutic Targets for Human Disease. Front Genet 10: 205.

Havens MA, Duelli DM and Hastings ML. (2013) Targeting RNA splicing for disease therapy. Wiley Interdiscip Rev RNA 4: 247-266.

Hedlund PB, Kelly L, Mazur C, et al. (2004) 8-OH-DPAT acts on both 5-HT1A and 5-HT7 receptors to induce hypothermia in rodents. Eur J Pharmacol 487: 125-132.

Heisler LK, Zhou L, Bajwa P, et al. (2007) Serotonin 5-HT(2C) receptors regulate anxiety-like behavior. Genes Brain Behav 6: 491-496.

Hubbard PC, Thompson AJ and Lummis SC. (2000) Functional differences between splice variants of the murine 5-HT(3A) receptor: possible role for phosphorylation. Brain Res Mol Brain Res 81: 101-108.

Issler O, Haramati S, Paul ED, et al. (2014) MicroRNA 135 is essential for chronic stress resiliency, antidepressant efficacy, and intact serotonergic activity. Neuron 83: 344-360.

Jakubauskiene E, Janaviciute V, Peciuliene I, et al. (2012) G/A polymorphism in intronic sequence affects the processing of MAO-B gene in patients with Parkinson disease. FEBS Lett 586: 3698-3704.

Jean A, Conductier G, Manrique C, et al. (2007) Anorexia induced by activation of serotonin 5-HT4 receptors is mediated by increases in CART in the nucleus accumbens. Proc Natl Acad Sci U S A 104: 16335-16340.

Karg K, Burmeister M, Shedden K, et al. (2011) The serotonin transporter promoter variant (5HTTLPR), stress, and depression meta-analysis revisited: evidence of genetic moderation. Arch Gen Psychiatry 68: 444-454.

Kelemen O, Convertini P, Zhang Z, et al. (2013) Function of alternative splicing. Gene 514: 1-30.

Khanzada NS, Butler MG and Manzardo AM. (2017) GeneAnalytics Pathway Analysis and Genetic Overlap among Autism Spectrum Disorder, Bipolar Disorder and Schizophrenia. Int J Mol Sci 18.

Kim SH, Seo M, Hwang H, et al. (2019) Physical and Functional Interaction between 5-HT6 Receptor and Nova-1. Exp Neurobiol 28: 17-29.

Kim SJ, Veenstra-VanderWeele J, Hanna GL, et al. (2000) Mutation screening of human 5HT(2B)receptor gene in early-onset obsessive-compulsive disorder. Mol Cell Probes 14: 4752.

Kloiber S, Kohli MA, Brueckl T, et al. (2010) Variations in tryptophan hydroxylase 2 linked to decreased serotonergic activity are associated with elevated risk for metabolic syndrome in depression. Mol Psychiatry 15: 736-747.

Krobert KA, Bach T, Syversveen T, et al. (2001) The cloned human 5-HT7 receptor splice variants: a comparative characterization of their pharmacology, function and distribution. Naunyn Schmiedebergs Arch Pharmacol 363: 620-632.

Krobert KA and Levy FO. (2002) The human 5-HT7 serotonin receptor splice variants: constitutive activity and inverse agonist effects. Br J Pharmacol 135: 1563-1571.

Le Francois B, Zhang L, Mahajan GJ, et al. (2018) A Novel Alternative Splicing Mechanism That Enhances Human 5-HT1A Receptor RNA Stability Is Altered in Major Depression. J Neurosci 38: 8200-8210.

Lev Maor G, Yearim A and Ast G. (2015) The alternative role of DNA methylation in splicing regulation. Trends Genet 31: 274-280.

Lipscombe D and Lopez Soto EJ. (2019) Alternative splicing of neuronal genes: new mechanisms and new therapies. Current Opinion in Neurobiology 57: 26-31. 
Lira A, Zhou M, Castanon N, et al. (2003) Altered depression-related behaviors and functional changes in the dorsal raphe nucleus of serotonin transporter-deficient mice. Biol Psychiatry 54: 960-971.

Liu MT, Kuan YH, Wang J, et al. (2009) 5-HT4 receptor-mediated neuroprotection and neurogenesis in the enteric nervous system of adult mice. J Neurosci 29: 9683-9699.

Lucas G, Rymar VV, Du J, et al. (2007) Serotonin(4) (5-HT(4)) receptor agonists are putative antidepressants with a rapid onset of action. Neuron 55: 712-725.

Maillet M, Robert SJ and Lezoualc'h F. (2004) New insights into serotonin 5-HT4 receptors : a novel therapeutic target for Alzheimer's disease? Curr Alzheimer Res 1: 79-85.

Mallajosyula JK, Kaur D, Chinta SJ, et al. (2008) MAO-B elevation in mouse brain astrocytes results in Parkinson's pathology. PLoS One 3: e1616.

Manfra O, Van Craenenbroeck K, Skieterska K, et al. (2015) Downregulation of 5-HT7 Serotonin Receptors by the Atypical Antipsychotics Clozapine and Olanzapine. Role of Motifs in the CTerminal Domain and Interaction with GASP-1. ACS Chem Neurosci 6: 1206-1218.

Maron E, Kuikka JT, Ulst K, et al. (2004) SPECT imaging of serotonin transporter binding in patients with generalized anxiety disorder. Eur Arch Psychiatry Clin Neurosci 254: 392-396.

Martin CB, Hamon M, Lanfumey L, et al. (2014) Controversies on the role of 5-HT(2C) receptors in the mechanisms of action of antidepressant drugs. Neurosci Biobehav Rev 42: 208-223.

Martin CB, Ramond F, Farrington DT, et al. (2013) RNA splicing and editing modulation of 5-HT(2C) receptor function: relevance to anxiety and aggression in VGV mice. Mol Psychiatry 18: 656665.

McGlincy NJ and Smith CW. (2008) Alternative splicing resulting in nonsense-mediated mRNA decay: what is the meaning of nonsense? Trends Biochem Sci 33: 385-393.

Mendez-David I, David DJ, Darcet F, et al. (2014) Rapid anxiolytic effects of a 5-HT(4) receptor agonist are mediated by a neurogenesis-independent mechanism. Neuropsychopharmacology 39: 1366-1378.

Meneses A. (2014) 5-HT7 receptor stimulation and blockade: a therapeutic paradox about memory formation and amnesia. Front Behav Neurosci 8: 207.

Menon V and Kattimani S. (2015) Suicide and Serotonin: Making Sense of Evidence. Indian J Psychol Med 37: 377-378.

Molderings GJ. (2012) Physiological, pathophysiological and therapeutic impact of the enteric serotonergic system. Arzneimittelforschung 62: 157-166.

Monti JM. (2011) Serotonin control of sleep-wake behavior. Sleep Med Rev 15: 269-281.

Morozova M, Burminskiy D, Rupchev G, et al. (2017) 5-HT6 Receptor Antagonist as an Adjunct Treatment Targeting Residual Symptoms in Patients With Schizophrenia: Unexpected SexRelated Effects (Double-Blind Placebo-Controlled Trial). J Clin Psychopharmacol 37: 169-175.

Murray KC, Nakae A, Stephens MJ, et al. (2010) Recovery of motoneuron and locomotor function after spinal cord injury depends on constitutive activity in $5-\mathrm{HT} 2 \mathrm{C}$ receptors. Nat Med 16: 694-700.

Nebigil CG, Choi DS, Dierich A, et al. (2000) Serotonin 2B receptor is required for heart development. Proc Natl Acad Sci U S A 97: 9508-9513.

Nichols DE and Nichols CD. (2008) Serotonin receptors. Chem Rev 108: 1614-1641.

Olsen MA, Nawoschik SP, Schurman BR, et al. (1999) Identification of a human 5-HT6 receptor variant produced by alternative splicing. Brain Res Mol Brain Res 64: 255-263.

Ottenhof KW, Sild M, Levesque ML, et al. (2018) TPH2 polymorphisms across the spectrum of psychiatric morbidity: A systematic review and meta-analysis. Neurosci Biobehav Rev 92: 2942.

Ozsarac N, Santha E and Hoffman BJ. (2002) Alternative non-coding exons support serotonin transporter mRNA expression in the brain and gut. J Neurochem 82: 336-344. 
Palma-Gudiel H and Fananas L. (2017) An integrative review of methylation at the serotonin transporter gene and its dialogue with environmental risk factors, psychopathology and 5HTTLPR. Neurosci Biobehav Rev 72: 190-209.

Pan YF, Zhang JY, Qiu HM, et al. (2019) Association of polymorphisms in HTR2A, TPH1, and TPH2 genes with attempted suicide in rural China. Psychiatr Genet 29: 79-85.

Peitl V, Stefanovic M and Karlovic D. (2017) Depressive symptoms in schizophrenia and dopamine and serotonin gene polymorphisms. Prog Neuropsychopharmacol Biol Psychiatry 77: 209215.

Pindon A, van Hecke G, van Gompel P, et al. (2002) Differences in signal transduction of two 5-HT4 receptor splice variants: compound specificity and dual coupling with Galphas- and Galphai/o-proteins. Mol Pharmacol 61: 85-96.

Pompili M, Gentile G, Scassellati C, et al. (2017) Genetic association analysis of serotonin and signal transduction pathways in suicide attempters from an Italian sample of psychiatric patients. Neurosci Lett 656: 94-102.

Porazinski S and Ladomery M. (2018) Alternative Splicing in the Hippo Pathway-Implications for Disease and Potential Therapeutic Targets. Genes (Basel) 9.

Pratelli M and Pasqualetti M. (2018) Serotonergic neurotransmission manipulation for the understanding of brain development and function: Learning from Tph2 genetic models. Biochimie.

Puig MV and Gulledge AT. (2011) Serotonin and prefrontal cortex function: neurons, networks, and circuits. Mol Neurobiol 44: 449-464.

Ramirez MJ. (2013) 5-HT6 receptors and Alzheimer's disease. Alzheimers Res Ther 5: 15.

Rebholz H, Friedman E and Castello J. (2018) Alterations of Expression of the Serotonin 5-HT4 Receptor in Brain Disorders. Int J Mol Sci 19.

Rivera M, Gutierrez B, Molina E, et al. (2009) High-activity variants of the UMAOA polymorphism increase the risk for depression in a large primary care sample. Am J Med Genet $B$ Neuropsychiatr Genet 150B: 395-402.

Rocha-Gonzalez HI, Meneses A, Carlton SM, et al. (2005) Pronociceptive role of peripheral and spinal 5-HT7 receptors in the formalin test. Pain 117: 182-192.

Ruble CL, Smith RM, Calley J, et al. (2016) Genomic structure and expression of the human serotonin 2A receptor gene (HTR2A) locus: identification of novel HTR2A and antisense (HTR2A-AS1) exons. BMC Genet 17: 16.

Sarkisyan G, Roberts AJ and Hedlund PB. (2010) The 5-HT(7) receptor as a mediator and modulator of antidepressant-like behavior. Behav Brain Res 209: 99-108.

Schellekens H, Clarke G, Jeffery IB, et al. (2012) Dynamic 5-HT2C receptor editing in a mouse model of obesity. PLoS One 7: e32266.

Segelcke D and Messlinger K. (2017) Putative role of 5-HT2B receptors in migraine pathophysiology. Cephalalgia 37: 365-371.

Stamm S, Gruber SB, Rabchevsky AG, et al. (2017) The activity of the serotonin receptor 2C is regulated by alternative splicing. Hum Genet 136: 1079-1091.

Su CH, D D and Tarn WY. (2018) Alternative Splicing in Neurogenesis and Brain Development. Front Mol Biosci 5: 12.

Sun Y, Zhang J, Yuan Y, et al. (2012) Study of a possible role of the monoamine oxidase A (MAOA) gene in paranoid schizophrenia among a Chinese population. Am J Med Genet $B$ Neuropsychiatr Genet 159B: 104-111.

Takehashi M, Tanaka S, Masliah E, et al. (2002) Association of monoamine oxidase A gene polymorphism with Alzheimer's disease and Lewy body variant. Neurosci Lett 327: 79-82.

Tanaka M, Sato A, Kasai S, et al. (2018) Brain hyperserotonemia causes autism-relevant social deficits in mice. Mol Autism 9: 60. 
Tauscher J, Pirker W, Willeit M, et al. (2001) [123I] beta-CIT and single photon emission computed tomography reveal reduced brain serotonin transporter availability in bulimia nervosa. Biol Psychiatry 49: 326-332.

Thomas SJ, Shin M, McInnis MG, et al. (2015) Combination therapy with monoamine oxidase inhibitors and other antidepressants or stimulants: strategies for the management of treatment-resistant depression. Pharmacotherapy 35: 433-449.

Turecki G, Ernst C, Jollant F, et al. (2012) The neurodevelopmental origins of suicidal behavior. Trends Neurosci 35: 14-23.

Twitchell GR, Hanna GL, Cook EH, et al. (2001) Serotonin transporter promoter polymorphism genotype is associated with behavioral disinhibition and negative affect in children of alcoholics. Alcohol Clin Exp Res 25: 953-959.

Tzvetkov MV, Meineke C, Oetjen E, et al. (2007) Tissue-specific alternative promoters of the serotonin receptor gene HTR3B in human brain and intestine. Gene 386: 52-62.

Vaswani M, Linda FK and Ramesh S. (2003) Role of selective serotonin reuptake inhibitors in psychiatric disorders: a comprehensive review. Prog Neuropsychopharmacol Biol Psychiatry 27: 85-102.

Vijayendran M, Cutrona C, Beach SR, et al. (2012) The relationship of the serotonin transporter (SLC6A4) extra long variant to gene expression in an African American sample. Am J Med Genet B Neuropsychiatr Genet 159B: 611-612.

Wahl MC, Will CL and Luhrmann R. (2009) The spliceosome: design principles of a dynamic RNP machine. Cell 136: 701-718.

Waider J, Araragi N, Gutknecht L, et al. (2011) Tryptophan hydroxylase-2 (TPH2) in disorders of cognitive control and emotion regulation: a perspective. Psychoneuroendocrinology 36: 393405.

Wang ET, Ward AJ, Cherone JM, et al. (2015) Antagonistic regulation of mRNA expression and splicing by CELF and MBNL proteins. Genome Res 25: 858-871.

Weisstaub NV, Zhou M, Lira A, et al. (2006) Cortical 5-HT2A receptor signaling modulates anxiety-like behaviors in mice. Science 313: 536-540.

Xiang C, Liu S, Fan Y, et al. (2019) Single nucleotide polymorphisms, variable number tandem repeats and allele influence on serotonergic enzyme modulators for aggressive and suicidal behaviors: A review. Pharmacol Biochem Behav 180: 74-82.

Zhang G and Stackman RW, Jr. (2015) The role of serotonin 5-HT2A receptors in memory and cognition. Front Pharmacol 6: 225.

Zhang X, Nicholls PJ, Laje G, et al. (2011) A functional alternative splicing mutation in human tryptophan hydroxylase-2. Mol Psychiatry 16: 1169-1176.

Zhang Z, Shen M, Gresch PJ, et al. (2016) Oligonucleotide-induced alternative splicing of serotonin $2 \mathrm{C}$ receptor reduces food intake. EMBO Mol Med 8: 878-894.

Zhu LY, Zhu YR, Dai DJ, et al. (2018) Epigenetic regulation of alternative splicing. Am J Cancer Res 8: 2346-2358. 
Figure 1: Schematic representation of alternative splicing process. The diagram illustrates how alternative splicing allows the production of different variants of the same protein from the same gene. Starting from a single gene (DNA coding sequence), the spliceosome (represented by 4 green units) can include or excluded the intron1 in a co-transcriptional process, creating two different mRNAs that will be traduced in two similar proteins (isoforms) but with different function properties.

Figure 2: Alternative splicing of serotonergic system. 5-HT levels are controlled by the activity of TPH2, SERT and MAO-A. TPH2 has three spiced variants: TPH2a, TPH2b and TPH2-TR. The TPH2a variant presents a reduced activity compared with TPH2b. On the contrary, TPH2-TR is a truncated isoform with a lack of activity. SERT has three spliced variants (SERT-1A, SERT-1AB, SERT-1C) which are differentially polyadenylated and differ in their translational regulations. MAO-A is alternative spliced, creating a less efficient isoform (MAO-A short). Alternative splicing of these three genes could seriously impact on $5-\mathrm{HT}$ levels playing a critical role in neuropsychiatric disorders. Regarding 5-HT receptors, there are numerous spliced variants presenting differences in their activity, expression, regulation, structure and sensitivities to ligands.

\begin{abstract}
Table1: Serotonergic system components, alternative spliced isoforms and their implication in neuropsychiatric disorders. Genetic information obtained by $\mathrm{NCBI}$ and Genetics Home Reference $(\mathrm{NIH})$.
\end{abstract}






Figure 1

$266 \times 181 \mathrm{~mm}(150 \times 150 \mathrm{DPI})$ 


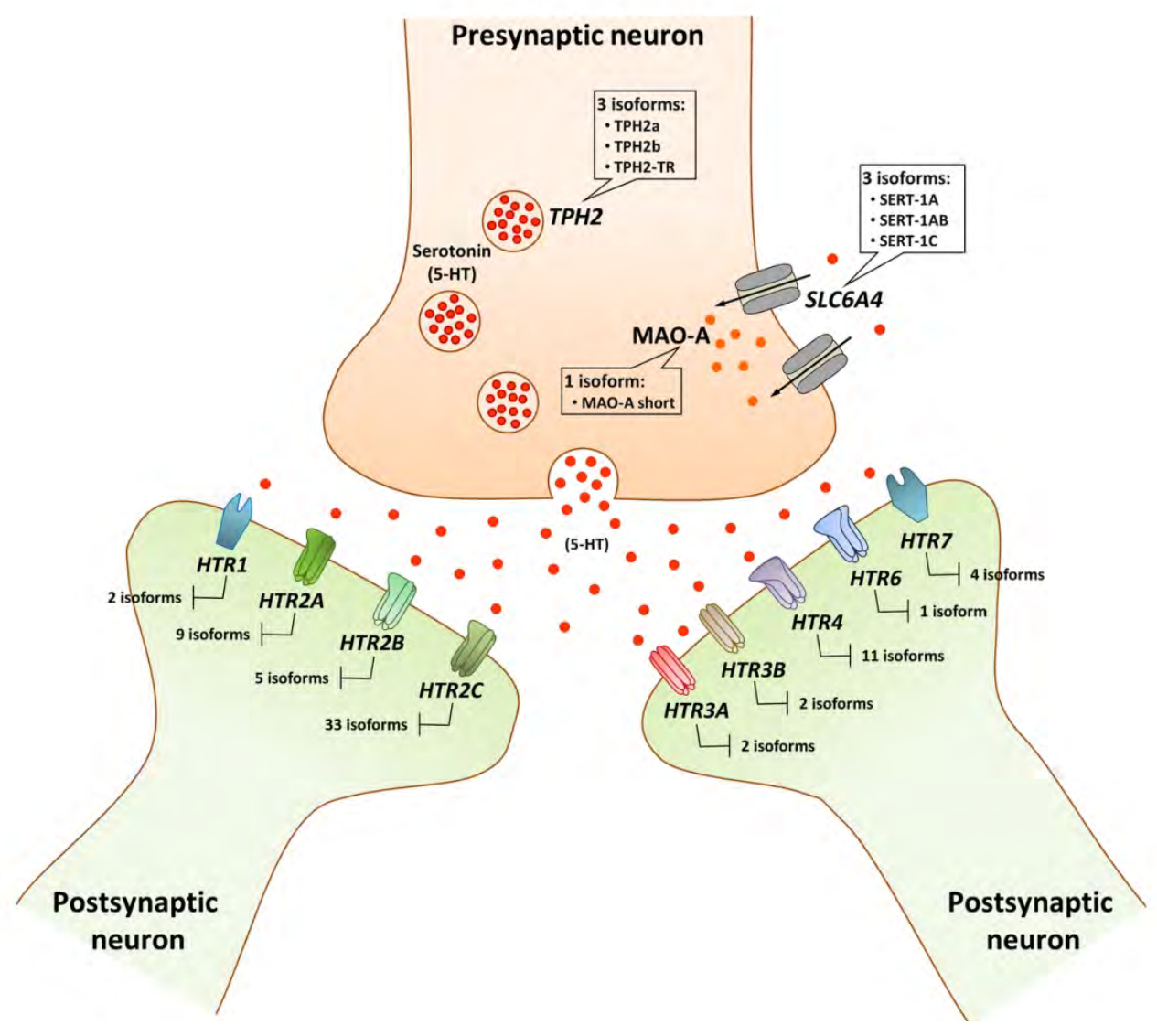

Figue 2

$119 \times 104 \mathrm{~mm}(300 \times 300 \mathrm{DPI})$ 
Table 1: Serotonergic components and their implication on neuropsychiatric pathologies

\begin{tabular}{|c|c|c|c|c|c|c|}
\hline Name & Gene & Location & Intron/exon & $\begin{array}{l}\text { Spliced } \\
\text { Isoforms }\end{array}$ & References & Related Neuropsychiatric Pathologies \\
\hline $\begin{array}{l}\text { Tryptophan } \\
\text { hydroxylase-2 }\end{array}$ & $\mathrm{TPH} 2$ & $12 q 21.1$ & $\begin{array}{l}10 \text { introns } \\
11 \text { exons }\end{array}$ & 3 & $\begin{array}{l}\text { Grohmann et al., } 2010 \\
\text { Zhang et al., } 2011\end{array}$ & $\begin{array}{l}\text { Depression (Gao et al., 2012) , Bipolar Disorder (Khanzada } \\
\text { et al., 2017), ADHD (Ottenhof et al., 2018), Suicidal } \\
\text { behaviour (Pompili et al., 2017), Autism (Egawa et al., 2013) }\end{array}$ \\
\hline $\begin{array}{l}\text { Serotonin } \\
\text { transporter }\end{array}$ & SLC6A4 & $17 q 11.2$ & $\begin{array}{l}13 \text { introns } \\
14 \text { exons }\end{array}$ & 3 & $\begin{array}{l}\text { Ozsarac et al., } 2002 \\
\text { (Gill et al., 2008) }\end{array}$ & $\begin{array}{l}\text { Bipolar Disorder (Chou et al., 2016), Depression (Peitl et al., } \\
\text { 2017), Autism (Tanaka et al., 2018), Neuroticism, Alcohol } \\
\text { dependence (Twitchell et al., 2001), Anxiety (Maron et al., } \\
\text { 2004), Eating disorders (Tauscher et al., 2001) }\end{array}$ \\
\hline $\begin{array}{l}\text { Monoamine } \\
\text { oxidase A }\end{array}$ & MAOA & Xp11.3 & $\begin{array}{l}14 \text { introns } \\
15 \text { exons }\end{array}$ & 1 & Biondo, 2017 & $\begin{array}{l}\text { Schizophrenia (Sun et al., 2012), Depression (Thomas et al., } \\
\text { 2015), Alzheimer's disease (Cai, 2014), Aggressive behaviour } \\
\text { (Frau et al., 2019) }\end{array}$ \\
\hline $\begin{array}{l}\text { Serotonin } \\
\text { receptor } 1 \mathrm{~A}\end{array}$ & HTR1A & $5 q 63.26$ & 1 exon & 2 & Le Francois et al., 2018 & Anxiety, Major Depression (Garcia-Garcia et al., 2014) \\
\hline \multirow{3}{*}{$\begin{array}{l}\text { Serotonin } \\
\text { receptor } 2\end{array}$} & HTR2A & $13 q 14.2$ & $\begin{array}{l}3 \text { introns } \\
4 \text { exons }\end{array}$ & 9 & $\begin{array}{l}\text { Ruble et al., } 2016 \\
\text { Guest et al., } 2000\end{array}$ & $\begin{array}{l}\text { Schizophrenia (Abi-Dargham, 2007), Cognition (Blasi et al., } \\
\text { 2013), Depression, Alcohol dependence, Anxiety (Ghasemi et } \\
\text { al., 2018) }\end{array}$ \\
\hline & HTR2B & $2 q 37.1$ & $\begin{array}{l}3 \text { introns } \\
4 \text { exons }\end{array}$ & 5 & Kim et al., 2000 & $\begin{array}{l}\text { Obsessive-compulsive disorder, Anxiety (de Leeuw and } \\
\text { Westenberg, 2008), Migraine (Segelcke and Messlinger, 2017) }\end{array}$ \\
\hline & HTR2C & $\mathrm{Xq23}$ & $\begin{array}{l}5 \text { introns } \\
6 \text { exons }\end{array}$ & 33 & $\begin{array}{l}\text { Stamm et al., } 2017 \\
\text { Zhang et al., } 2016\end{array}$ & $\begin{array}{l}\text { Depression (Martin et al., 2014), Anxiety (Monti, 2011),, } \\
\text { Obesity (Garfield et al., 2016), Schizophrenia (Castensson et al., } \\
\text { 2005),Suicidal behaviour (Chagraoui et al., 2016) }\end{array}$ \\
\hline \multirow{2}{*}{$\begin{array}{l}\text { Serotonin } \\
\text { receptor } 3\end{array}$} & HTR3A & $11 q 23$. & $\begin{array}{l}7 \text { introns } \\
8 \text { exons }\end{array}$ & 2 & Hubbard et al., 2000 & $\begin{array}{l}\text { Cognition Disturbances (Costall and Naylor, 2004), Analgesia, } \\
\text { Schizophrenia, Bipolar disorder (Chameau and van Hooft, 2006) }\end{array}$ \\
\hline & HTR3B & $11 q 23.2$ & $\begin{array}{l}8 \text { introns } \\
9 \text { exons }\end{array}$ & 2 & Tzvetkov et al., 2007 & $\begin{array}{l}\text { Schizophrenia, Depression, Addiction, Obsessive-compulsive } \\
\text { disorder(Chameau and van Hooft, 2006) }\end{array}$ \\
\hline $\begin{array}{l}\text { Serotonin } \\
\text { receptor } 4\end{array}$ & HTR4 & $5 q 32$ & $\begin{array}{l}7 \text { introns } \\
8 \text { exons }\end{array}$ & 11 & Rebholz et al., 2018 & $\begin{array}{l}\text { Alzheimer's disease (Maillet et al., 2004), Anxiety (Bockaert et } \\
\text { al., 2004), Anorexia nervosa (Jean et al., 2007), Depression }\end{array}$ \\
\hline
\end{tabular}




\begin{tabular}{|c|c|c|c|c|c|c|}
\hline & & & & & & (Amigo et al., 2016) \\
\hline $\begin{array}{l}\text { Serotonin } \\
\text { receptor } 6\end{array}$ & HTR6 & $1 p 36.13$ & $\begin{array}{c}2 \text { introns } \\
3 \text { exons }\end{array}$ & 1 & Olsen et al., 1999 & $\begin{array}{l}\text { Schizophrenia (Morozova et al., 2017), Depression, Anxiety, } \\
\text { Cognitive disturbances (de Bruin and Kruse, 2015), Alzheimer's } \\
\text { disease (Ramirez, 2013) }\end{array}$ \\
\hline $\begin{array}{l}\text { Serotonin } \\
\text { receptor } 7\end{array}$ & HTR7 & $10 q 21.31$ & $\begin{array}{l}3 \text { introns } \\
4 \text { exons }\end{array}$ & 4 & $\begin{array}{l}\text { Guthrie et al., } 2005 \\
\text { Krobert and Levy, } 2002\end{array}$ & $\begin{array}{l}\text { Analgesia, Migraine, Schizophrenia (Manfra et al., 2015), } \\
\text { Anxiety, Inflammation (Rocha-Gonzalez et al., 2005), Cognitive } \\
\text { disturbances (Meneses, 2014) }\end{array}$ \\
\hline
\end{tabular}

